cIbgcIi5cAaPCqiQqRwQHJk11FSGLjFHIHgth1wQqc17NHzDR_jAXRs (дата звернення 27.11.2020)

7. Харун О.А. Розвиток корпоративного управління в умовах глобалізації. Східна Європа: Економіка, Бізнес та Управління. 2018. Випуск 6 (17). C. 409-415. URL: https://chmnu.edu.ua/wpcontent/uploads/2019/07/Harun-O.А..pdf (дата звернення 27.11.2020)

8. OECD Principles of Corporate Governance. OECD 2004. URL: https://www.oecd.org/corporate/ca/corporategovernanceprinciples/315 57724.pdf (дата звернення 27.11.2020)

9. Про заходи щодо розвитку корпоративного управління в акціонерних товариствах: Указ Президента України від 21.03.2002 p. № 280/2002. URL: https://zakon.rada.gov.ua/laws/show/280/2002\#Text (дата звернення 27.11.2020)

DOI https://doi.org/10.30525/978-9934-26-045-2-4

\title{
A SURVEY RESEARCH METHOD AS A TOOL TO GRASP FISCAL DECENTRALIZATION IN UKRAINE
}

\author{
Kovalchuk A. V. \\ Ph.D. Student at School of Economics \\ Shandong University \\ Shandong, China
}

To date, fiscal decentralization (FD) has been advocated throughout the world. Examples are prevalent around the world: functional devolution, decentralization of fiscal decision-making and public administration, and socioeconomic reforms (from centralized to decentralized economies) in Asian and Eastern European countries. In Ukraine at the same was launched about seven years ago.

The circumstantial evidence is that FD is suggested to improve the performance of the public sector; the common evidence is that FD is considered to have the potential to foster economic development and institutional advancement. However, numerous studies adhere to the conventional argument that FD may raise economic efficiency in the public sector has a possibility not to be suitable in developing countries. Moreover, 
the conventional argument regarding functional revenue assignment and expenditure responsibilities has been challenged on repeated occasions.

Thus, a critical pending issue of FD is its applicability in developing economies like Ukraine. The review on international research regarding decentralization confirmed that the level of economic development of a single country, measured by income, urbanization, business and institutional conditions, technology advancement, and Gross Domestic Product (GDP), is associated with a significantly greater local share of expenditure, by so drawing in the public policies to promote FD are more likely to be effective for developed countries [4].

This research brings up following matters of FD. First, numerous decentralization studies have tended to be theoretical rather than empirical; consequently, it is needed to verify these polemical arguments in an analytical setting. Second, most empirical decentralization studies are limited to the U.S., China, and other developed countries. Third reason is the difficulty of obtaining reliable fiscal data from developing countries. In order to grasp the FD accurately, it is important to carry out its systematic analysis exactly in developing country. Finally, this study may donate to formulate upcoming intergovernmental fiscal policy in Ukraine, as current implementation of FD is a relatively new phenomenon; policy-makers are desperately hard up for supplementary input on this matter.

The recent implementation of FD in Ukraine offers an excellent opportunity for empirical evaluation of this assumption, as Ukraine represents the borderline case between developed and developing countries, by so, a decentralization study upon Ukrainian case will help out to testify on the liaison whether or not there is efficiency gain in countries in transition, as well as examining the issue of revenue and expenditure assignment farther afield developed countries. In recent years, the efforts to systematically investigate the actual effects of FD on the economic advancement are few, especially those on initial stage of decentralization reform and under conditions of economy stagnation.

During the 2013 and 2018, many local governments have been consolidated into hromadas, for which consistent data could be collected. As a result, as of January 2018, almost 700 united territorial communities (hromadas) were created in Ukraine, which included 3264 local communities or $29.1 \%$ of the total number of primary level councils as of January 1 , 2015 , i.e., before the start of the FD. The population of the united 
communities was 6 million or $14.3 \%$ of the total population of Ukraine. On July 17, 2020, the Verkhovna Rada of Ukraine adopted Resolution № 3650 «On the formation and liquidation of districts» [2]. According to the document, there are now 136 districts in Ukraine. The old 490 districts were liquidated. After the Amendments to the Budget and Tax Codes of Ukraine and according to official data: local budgets increased by UAH 206.4 billion: from UAH 68.6 billion in 2014 to UAH 275 billion in 2019. A capable basic level of local self-government has been shaped. In 2015-2019, 982 amalgamated territorial communities (ATC) were voluntarily established in Ukraine. These ATC included about 4,500 former local councils; recently about 11 million people reside in ATC. Such rates of inter-municipal consolidation are called very high by international experts. According to the Law «On Voluntary Amalgamation of Territorial Communities» the institute of starosta, who represent the interests of rural residents in the community council, was implemented in the ATCs. In 2018, the hromadas received almost 1.5 million hectares of agricultural land outside the settlements.

According to practice in Ukraine, local self-government generally carries out delegated powers, including education (reaching $31 \%$ of total local budget expenditures), social protection and social security (26\%), health (22\%) [1]. However, the problem of inefficient spending of budgetary resources is still unresolved due to the existence of outdated mechanisms for financing public institutions. It is on the estimated financing of public institutions, which consumes up to $60 \%$ of local budget expenditures. A significant differentiation of local budgets is defined by the geographical dimension, the development of infrastructure, the scale of reforms, which reflect the increase of fundamental differences in the distribution of tax capacity in the country, differences in the structure of budget financing needs, and the budgets' conditions.

For instance, in the context of FD, in addition to the existing state taxes, granting the right to local authorities to establish their own local taxes and change tax rates affects the number of revenues collected for the local budgets in Ukraine. According to the Budget Code of Ukraine, personal income tax is distributed between state and local budgets. Hence, apparent increase in shares of total budget revenues and expenditures is shown in Figure 1. 

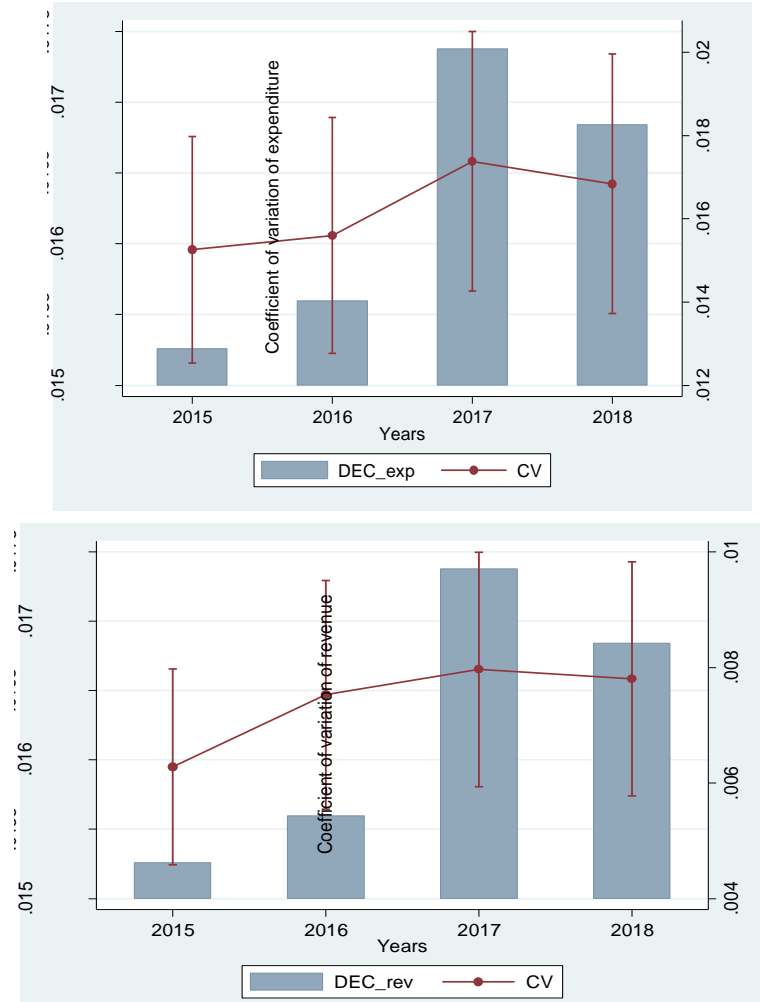

Fig. 1. Budgetary expenditure (figure on the left) and revenue (figure on the right) decentralization

Hence, changing the standard of delimitation of personal income tax between local and state budgets has significantly affected the formation of revenues collected for local budgets. Personal income tax is dominant in the number of fixed revenues of local budgets and is not less than $60 \%$ of their income. Such tax is the most important in terms of revenue collection for local budgets. As Figure 1shows, and in accord with reports of the Ministry of Finance of Ukraine, and in line with recent research findings, the actual growth rate of the personal income tax revenues for 2015 to 2017 was $123.1 \%$ [3].

To ascertain the effects of FD as perceived by local officials, a survey research method was utilized to collect supplementary data. During the 
period of February 2021 until now, a questionnaire was forwarded to the local officials in 31 local governments in Zhytomyr region, including oblast, rayon, and hromada levels. Thirteen local officials returned usable questionnaires ( $41.93 \%$ return rate). The questionnaire includes 13 questions of which one is open-ended and 11 are closed ended. These questions are designed to ascertain the effects of FD policies as perceived by local officials. To generate the data we apply the analytic hierarchy process (AHP) as a multi-criteria decision method. AHP allows us to go with flexible decision hierarchies, supports the improvement of inconsistent judgments, and provides alternative evaluation and sensitivity evaluation. The distribution of the respondents is shown in Table 1 . The responses by local government types are representative of the population as a whole; no government type is underrepresented.

Table 1

Frequency of Questionnaire Response by the Levels of Government

\begin{tabular}{|c|c|c|c|}
\hline No & $\begin{array}{c}\text { Number of } \\
\text { samples }\end{array}$ & $\begin{array}{c}\text { Number of } \\
\text { responses }\end{array}$ & Return rate \\
\hline Zhytomyr & 1 & 1 & $100 \%$ \\
\hline Oblast level & 8 & 4 & $50 \%$ \\
\hline Rayon level & 11 & 3 & $27.3 \%$ \\
\hline Hromada & 11 & 5 & $45.5 \%$ \\
\hline
\end{tabular}

Source: own compilation

In the survey, 7 out of 13 local government officials respond that they put the most emphasis on economic development. Two out of 13 local governments respond that they put the most emphasis on welfare function. From these survey results, we may notice that the two most important policy areas in local governments are economic development and welfare functions. Out of 13 responses, 6 local officials confirm that in comparison with 2014, local government is now operating the budget more independently from the central government. Out of 13 responses, 12 local officials agree local council plays a substantial role in determining the final budget outcome; they also agree there is a cooperative relationship between the local assembly and the budget office. In expenditure area the local government receives the most discretion from the central government according to 8 respondents. Out of 13 responses, 5 local officials believe the influence of the central government on local government is still profound. All 13 respondents stated that income tax is the most critical for the formation of the local budget. Even though substantial percentages of local officials 
(7 out of 13) respond that the local assembly plays an important role in determining the final budget outcome, the role of the local assembly is somewhat limited because of its short history and lack of expertise. Out of 12 , only 1 local official responds that local public officials are well equipped with professional knowledge about budget substance.

The central level should commend a primarily authority on non-benefit taxes and the local level government should commend a primarily authority on benefit taxes. To settle the issue on prescription of revenue assignments and to minimize economic distortion prompted by misallocation of benefit and non-benefit taxes, the policy makers should consider the following assumptions: the mobility cost of labor and capital economic units raises as the geographical size of administrative unit increases and (2) citizens are more tolerating the ratability if they receive valuable services.

Anyway, the issue on prescription of revenue assignments is not settled yet. Considering this fact, we scrutinize the following principles for tax assignment [5].

1. Highly progressive, redistributional taxes are better to be centralized, as may hazard economic development as they potentially may produce no potentially distorting incentives for movements among jurisdictions should be avoided at local level. 2. All in all, non-benefit taxes potentially may distort the locational pattern of economic activity and should avoid on highly mobile tax bases. 3. Local government, in particular, should employ taxes likes land tax, calculated on relatively immobile tax bases. 4 . Dues and taxes on natural resources to avoid geographical inequities and to prevent allocative distortions that can result from the local taxation of such resources are better advised to be centralized. 5. The central government should commend primary taxing authority upon those tax bases that are distributed across jurisdictions in a highly unequal pattern. 6 . While user charges and fees (natural resources, parking facilities, expenditures on higher education and hospitals) cannot, in principle, cause migration among jurisdictions, and should be exercised at as benefit taxes, as an appealing revenue instrument at local levels. 7. The issue on the lack of professionals should be addressed, as local government requires adequately shaped and trained staff and/or low qualification of local officials to perform new functions needs.

\section{References:}

1. Ministry of Finance of Ukraine, Budget of Ukraine 2018 Annual Report, Pp. 11-12. Available at: https://mof.gov.ua/storage/files/ Budget $\% 20$ of $\% 20$ Ukraine $\% 202018 \% 20$ (for $\% 20$ website).pdf

2. Ministry of Regional Development, Construction and Housing and Communal Services in Ukraine, Decentralization in Ukraine, [Online], 
available at URL: https://decentralization.gov.ua/news/4913, accessed on November 04, 2019.

3. Buletsa, N. 2017. Stimulyuvannya socialno-ekonomichnogo rozvitku regionu $\mathrm{v}$ umovah finansovoyi decentralizaciyi [Formation of the local selfgovernment budgets in conditions of fiscal decentralization]. Kyiv, PhD dissertation. [in Ukrainian]

4. Kwon, O. 2002. The Effects of Fiscal Decentralization on Public Spending: The Korean Case. School of Public and International Affairs. Available at: DOI https://doi.org/10.1111/j.0275-1100.2003.02304001.x

5. Quigley, J.M. and Smolensky, Eu. 1994. Modern public finance. Cambridge, Mass.: Harvard University Press.

DOI https://doi.org/10.30525/978-9934-26-045-2-5

\title{
ПУБЛІЧНЕ УПРАВЛІННЯ МІЖРЕГІОНАЛЬНИМИ КЛАСТЕРАМИ ЯК СУЧАСНИЙ ІНСТРУМЕНТ ПОЛІТИКИ РЕГІОНАЛЬНОГО РОЗВИТКУ
}

\author{
Корнієвський С. В. \\ кандидат наук з державного управління, \\ докторант кафедри економіки \\ та регіональної економічної політики \\ Дніпропетровського регіонального інституту \\ державного управління \\ Національної академії державного управління \\ при Президентові України \\ м. Дніпро, Украӥна
}

Виклики сьогодення вимагають модернізації управлінських підходів для вирішення завдань регіонального розвитку. Одним із таких підходів $є$ кластерний підхід, який, хоча і $є$ відносно новим, але вже потребує певного удосконалення та більш широкого використання в процесах формування та реалізації політики регіонального розвитку. В даній роботі розглядаються аспекти публічного управління у сфері створення та діяльності міжрегіональних кластерів.

Зараз і в Європі і світі в цілому традиційна кластерна політика, сформована в основному на «портерівских» моделях і концепціях, себе вичерпує - вона вже не є достатнім драйвером зростання. Потрібна модернізація кластерної теорії і вироблення моделей публічного управління кластерами, адаптованих до умов мінливого світу. Кластери повинні стати універсальним інструментом для розвитку територій. 